\title{
The musts for teaching english in secondary education: theory and practice
}

DOI: $10.46932 /$ sfjdv2n2-031

Received in: january 1st, 2020

Accepted in: March 30th, 2020

\author{
Sonia María Martínez Ponce \\ Máster profesorado. English teacher \\ Institution: RG Formación \\ Calle Rosalía de Castro, 44, 30107 Murcia
}

\begin{abstract}
This paper presents a conceptual approach — made after a detailed review of the current existing bibliography - of the current situation in relation to teaching in Secondary Education in Spain from a theoretical-legal point of view highlighting the importance of inclusive education - truthful and of quality-. This research also presents a practical intervention proposal to address assertiveness in the English classroom that will make a good account of the correct teaching involvement.
\end{abstract}

Keywords: English subject, teaching-learning process, SEN students, Education.

\section{ATTENTION TO DIVERSITY}

"No student behind, no talent wasted": what organization of attention to diversity would be necessary?

Another way to learn in high school

\section{What happens in schools?}

\begin{tabular}{|l|l|}
\hline Some time ago... & Since a time ago... \\
\hline Selected student & Obliged and unmotivated students \\
\hline Clear values & Contradictory values \\
\hline Homogeneous classrooms & Diversity and multiculturalism \\
\hline Authority and discipline & Culture of participation and equality: conflict \\
\hline Clear role of the teacher & Complex role of the teacher (counselor, advisor ...) \\
\hline High regard from the teacher & Low consideration of the teacher \\
\hline Low competitiveness & High competitiveness \\
\hline Stability, predictability & Instability, uncertainty \\
\hline
\end{tabular}

\section{1) "No student behind, no talent wasted"}

"Attention to the diversity of the students, the adaptation of the educational processes to the characteristics of each student, is the key to preventing failure. And the figures for this reach a magnitude that has been unbearable for our society".

\section{2) Models of attention to diversity}

Selective segregated /

model. 
Comprehensive / integrated / $\quad \mathrm{r}$ model.

- Inclusive / transformative model.

\section{3) Inclusive school:}

- Diversity is not an obstacle but an enrichment opportunity.

- All students count: "No student behind, no talent wasted "

- Moving towards inclusion means reducing barriers of various kinds that prevent or hinder everyone's access to learning "Learning excludes, above all, those who cannot access it"

○ Center models:

- The educational response of the non-inclusive center is not adapted to the specific needs of the students. Therefore, an inclusive center is required, whose educational response is in accordance with the specific needs of the students.

\section{4) Attention to diversity in the LOE:}

$>$ The LOE establishes that attention to diversity is a fundamental principle in basic education. The Educational Administrations will provide the necessary means for all students to achieve the maximum personal, intellectual, social and emotional development, as well as the objectives established in general.

Students with a specific need for educational support:

- STUDENTS WITH SEN. (specific educational supports and attention derived from disability or serious conduct disorders)

- STUDENTS WITH LATE INTEGRATION INTO THE SPANISH EDUCATIONAL SYSTEM

- STUDENTS WITH HIGH INTELLECTUAL CAPACITIES

- EDUCATIONAL COMPENSATION MEASURES of inequalities derived from social, economic, cultural, geographical, ethnic or other factors

\section{5) Measures of Attention to Diversity: LOE / 2006}

Structural: administration

- Schooling

- Means and resources

- Scholarships and grants

$>$ Organizational: center, management team 
- Support and reinforcement in instrumental subjects.

- Flexible groupings.

- Group splitting.

- Extension of school hours.

- Stay of 1 more year in the same course.

- Electives and optional.

Curriculars: teams of teachers and support staff

- Support and support programs

- Curriculum enrichment programs

- Welcome programs to the educational system

- Curriculum adaptation programs

- Adaptation of access to the curriculum

- Truancy Prevention and Educational Compensation Programs

- Specification of the curriculum

\section{Outcome:}

- CURRICULUM DIVERSIFICATION

- INITIAL PROFESSIONAL QUALIFICATION PROGRAMS

\section{6) General organizational measures:}

- Supports and reinforcements for the instrumental subjects - Split in 3 subjects: English, Technologies and Natural Sciences.

- Extension of the weekly school hours for students who need it. - Specific personalized measures for students who do not promote the course. - Organization of Electives

\section{1) Curricular measures of attention to diversity:}

Measures for students with educational compensation needs (OC July 4, 2001, DOCV 17/7):

* Students with educational compensation needs are considered to be those who have difficulties in finding a job because they are in an unfavorable situation, derived from social, economic, cultural, ethnic or personal circumstances. These needs may be due to:

- Late incorporation into the educational system

- Delay in schooling or lack of knowledge of the official languages due to being an emigrant or refugee. 
- Belonging to minorities in a situation of social disadvantage

- Irregular schooling or conditional on hospitalization.

- Maladjustments to the school environment ...

* Curricular and methodological measures (flexible groups, curricular areas ...)

* Extension of schooling

a) When the curricular gap is not very important.

b) It will affect the elements of the curriculum, methodology and contents, but without modifying the objectives, the $\mathrm{CC} \mathrm{BB}$ or the evaluation criteria.

c) Aimed at students with lag in their skills or with significant learning difficulties or access to the curriculum due to disability or conduct disorder.

d) Proposed by teachers, with the advice of the Guidance Department.

e) It does not affect the degree in the stage.

\section{$\underline{\text { Significant curricular adaptations }}$}

a) When the curricular gap with respect to the student's age group is at least 1 cycle (2 years), and makes it necessary to modify the elements of the curriculum, including the objectives, CC BB and the evaluation criteria.

b) It is aimed at students with specific, temporary or permanent educational needs, derived from physical, mental, sensory disabilities or with serious personality or behavior disorders.

c) It can entail schooling in specialized units, even in specific centers in the US.

d) Prepared by the teachers of the corresponding subjects, with the advice of the Guidance department, and applied by them and / or by the Therapeutic Pedagogy teacher.

e) It does not qualify for the title and requires parental authorization.

\section{Curriculum enrichment program for gifted students}

a) Measures aimed at students with high abilities, as well as to support schools that promote enrichment and deepening curricular measures for all students.

b) The centers, with the advice of the Department of guidance and approval of the School Council, will develop curricular enrichment projects in the subjects they consider. 
c) It may entail making your schooling more flexible: reduction of 1 year in Primary and 1 year in ESO.

\section{Curriculum Diversification Program}

- Aimed at students who, after psychopedagogical evaluation, require an organization of the contents, practical activities and subjects of the curriculum different from that established in general and a specific methodology, to achieve the objectives and cc bb of the stage and title of GES.- Organized in 1 or 2 courses

\section{$\underline{\text { Initial professional qualification programs }}$}

Basic training offer, adapted to the specific needs of students at risk of abandoning regulated Education or who have already done so, without obtaining the GES degree

Triple purpose: professionalizing, maturing and propaedeutic (completing basic training and continuing their training)

\section{Recipients:}

- Young people over 16 years of age who have not obtained the GES degree.

-Exceptionally, said age may be reduced to 15 years for those students who, once they have completed 2nd ESO, are not in a position to pass to 3rd, have already repeated once in ESO and voluntarily decide to join.

\section{MODALITIES:}

\section{Initial Professional Qualification Classrooms}

- Modality aimed at young people preferably in school, who want an early professional insertion and who could continue their training process.

- Its scope of implementation is constituted by the ordinary educational centers authorized for this purpose.

- It will last for 2 school years and its curriculum will include the 3 types of modules

Initial Professional Qualification Workshops

- Modality aimed at young people in school or not, between 16 and 21 years old, which will last 1 course, incorporating only the compulsory modules and those of a general nature.

- Its scope of implementation is, in addition to educational centers, non-profit organizations. 
Multipurpose programs

Similar to qualification classrooms, although including modules associated with Units of Competence belonging to more than one Level I professional qualification

Special initial professional qualification programs

\section{Pilot program to prevent and reduce absenteeism and early school leaving}

Aimed at students between 14 and 16 years old, who present at least 3 characteristics among these:

- Serious difficulties in adapting to the school environment and the educational environment, with the risk of social exclusion.

- Chronic or severe school absenteeism.

- Low expectations of obtaining the GESO degree due to accumulating a very accentuated educational delay.

- Intention to integrate into the world of work upon reaching working age.

- Unstructured socio-family context, without sufficient support and control

Curricular organization: 3 main areas of work:

- Practical scope: Work projects related to the world of work.

- Scope of basic competences.

- Area of personal, social and pre-employment development.

\section{HAPPENS: WELCOME PROGRAM TO THE EDUCATIONAL SYSTEM}

-Measure of temporary support for the reception and integration of newly incorporated foreign students.

-Methodology that integrates language learning with the contents and areas of the curriculum.

-Duration of between 3 and 6 months, not being able to exceed one school year.

\section{Curricular organization of the Program:}

-It will be organized in 2 areas: Linguistic-social and Linguistic-scientific.

-Each area will be taught by a single teacher.

-The Program will be completed with the attendance of the student to his ordinary group to study at least Foreign Language, Physical Education, technology and an optional subject 


\section{PAE: SCHOOL ACCOMPANIMENT PROGRAM}

Aimed at students:

- At an educational disadvantage

- With learning difficulties, especially in instrumental subjects.

- With insufficient work habits.

- Whose families cannot provide sufficient support in the school activity, but who acquire the explicit commitment to collaborate with the center and guarantee attendance at the program.

\section{Organization of the Program:}

-Between 2 and 4 groups, of at least 8 students of the profile described, who must have the explicit commitment of their families.

-These groups will work outside of school hours: 2 days at a rate of 2 hrs / day, or 1 day with 4 hrs. -Academic and extracurricular or complementary activities.

\section{BOW: SUPPORT AND REINFORCEMENT PROGRAM}

\section{Program description:}

Aimed at HEIs that educate a considerable part of ESO students in conditions of educational disadvantage associated with the environment, with generalized learning difficulties. Students for whom the other measures of attention to diversity applied by the center have not been adequate.

\section{AREAS OF ACTION:}

-Direct attention and academic performance of the student

-Intervention with families

-Relationship with the environment

\section{MORE MEASURES OR MORE OTHER THINGS?}

More...

\section{Contract Program OC 42/2014, of June 3, brings together:}

- Support and reinforcement in the instrumental subjects.

- Flexible groupings

-Extension of school hours

-Reinforcement and accompaniment programs 
-Curricular enrichment programs

-Reception programs to the educational system

-Programs for the prevention of school absenteeism and educational compensation

\section{THE LOMCE NEWS.....}

\section{From PDCs to LEARNING AND PERFORMANCE IMPROVEMENT PROGRAMS}

New Learning and Performance Improvement Programs:

- They will be implemented in the 2nd and 3rd years of ESO.

- The students will join these programs at the proposal of the teaching team to the parents or legal guardians.

- They will preferably be aimed at students who present relevant learning difficulties not attributable to lack of study or effort, and will include organizational and curricular adaptations: grouping of subjects in areas, specific methodology, practical activities, etc. ...

\section{From PQPI to BASIC VOCATIONAL TRAINING}

\section{NEW CYCLES OF BASIC VOCATIONAL TRAINING}

- They will be compulsory and free of charge.

- Duration: 2 years.

- It will be accessed on the recommendation of the ESO teaching team, with the consent of the legal guardians or of the student himself if he is emancipated, between 15 and 17 years of age, after having completed the 3rd year of ESO, or exceptionally having completed the 2nd year of ESO.

- The Basic Vocational Training cycles will guarantee the acquisition of the basic skills of lifelong learning, through the teaching of Spanish Language, Foreign Language, Social Sciences, where appropriate Co-official Language, and Mathematics and Sciences Applied to the Personal Context and Learning in a Professional Field.

- The pedagogical criteria will be adapted to the specific characteristics of the students and will encourage teamwork. Tutoring and educational and professional guidance will have special consideration.

From a single GESO Degree to SEVERAL DEGREES AT THE END OF BASIC EDUCATION

- $\quad$ TITLE GESO OPTION ACADEMIC TEACHINGS - HIGH SCHOOL 
- TITLE GESO OPTION TEACHINGS APPLIED - GM FP

- BASIC PROFESSIONAL TECHNICIAN TITLE - GM FP

THE 3 TITLES ARE EQUIVALENT FOR PURPOSES OF ACCESS TO PUBLIC AND PRIVATE JOBS

\section{The Moral Purpose of Education}

- I know my learning goals and I have a sense of control over my progress

- I know how to do a good job and I can direct my own learning

- My parents are involved in the school and I identify with it

- I enjoy using new technologies and I know how they can help me

- I know how they are evaluating me and what I need to improve

- I can get the job that I aspire to

- I can work with my classmates and learn from them and my teacher

- I know that if I need additional help or encouragement to improve, I will find the right support

- I am able to achieve a level 4 in language arts and mathematics before entering secondary school

- I learn a lot of interesting and different subjects

○ All this ... whatever my origin, my abilities or my starting point

\section{1) No student behind, no talent wasted: Make a virtue out of necessity ...}

- "Learning is understanding, and it is understood when one is able to transfer what has been learned to other situations, not only in school but in life outside of school."

- $\quad \square$ Stoll, Fink and Earl (2004) suggest some recommendations:

1. Encourage and keep students engaged and motivated by combining socialization activities, a relevant curriculum that requires imagination and creativity, and challenging tasks.

2. Start with what the students consider to be true, start from the "place" of their learning

3. Teach strategies to classify, organize and interpret information. What students need is to learn to connect ideas and identify and construct critical frames of reference in which to place information.

4. Promote independent and active learning, which provides them with tools to be responsible for it.

5. Make learning social, which means learning with others in collaborative contexts.

6. Capitalize on the diversity of students. Classroom teaching and the curriculum have to connect with students' experiences and discourses, which are increasingly defined by cultural and subcultural diversity, different linguistic backgrounds and practices that come from this diversity. 
7. Use ICT, not as a routine object but as a tool that establishes the protagonism of the student in their own learning.

8. Promote reflection on what they are learning, students learn better when they make explicit their processes, their achievements and what helps and hinders them.

9. Encourage strategies that allow students to evaluate their own learning.

10. Expand opportunities and environments to learn - school is not the only place where students learn, so it is important to consider what happens outside of it.

\section{TEACHERS IN TIMES OF CHANGE}

\section{Approach to a profession in construction}

1st) Having regard to the 4 PILLARS OF EDUCATION defined in the Delors Report (learning to know, learn to do, learn to live with others, learn to be), what professional competencies should the initial training and selection of teachers seek?

\section{THE PARADOXES OF A PROFESSION}

- Teachers are the main resource of the educational system.

However, there does not appear to be a significant social consensus about:

* the nature and purpose of their profession

* your authority

* the conditions of your work and career

- As a result: Society seems more interested in the "other" resources destined for education than in its teachers.

\section{THE TEACHING PROFESSION}

Particularities with respect to the rest of the professions:

- His initial training is debatable and disputed.

- Lacks the counterweight of an adult and free clientele

- It is a "team" profession that necessarily unfolds in the context of a singular social organization: the school.

- The results of their work are more uncertain and difficult to evaluate than in other professions.

- It has to face new and radical social demands.

Teachers of the 21st century face a double challenge:prospective and conceptual 
- Prospective:the changes associated with "the knowledge society" force us to consider learning as a fundamental factor. Therefore, it is a basic objective to have schools and teachers for the knowledge society.

- Conceptual: We must be interested in the training of teachers for the knowledge society (what training? How and who should train them? How to select them?). And, also, of the schools for the knowledge society.

It is a challenge that places teaching professionalism as a central issue: is the teacher part of the problem or part of the solution?

\section{FOR TEACHERS TO BE PART OF THE SOLUTION:}

We must rebuild unity around education and the role of the school around the 4 pillars of education from the Delors Report (1996):

Learn to know (to master the very instruments of knowledge)

Learn to do (to transfer school knowledge to other real-life settings)

Learn to live with others (to live and work on common projects)

Learning to be (to develop in an integrated way the intellectual, social, moral, emotional and physical dimension)

The subsequent question is: what teachers do we need for students to learn all this? Namely:

What professional competencies must teachers acquire for student success in the 4 pillars of education in the Delors Report?

4 types of competitions: scientific, methodological, social and personal.

\section{SCIENTIFIC COMPETENCES:}

- Mastery of the science or scientific area to be taught, but in a very different way from how they learned it.

- Disciplinary knowledge appropriate to the educational stage: specific didactics, psychology, pedagogy, sociology ...

- Digital competence (ICT).

- I am fluent in a foreign language (!) 


\section{METHODOLOGICAL COMPETENCES:}

- Contextualize scientific knowledge in the specific school context.

- Create a good classroom climate based on dialogue, trust, respect and shared work. Properly relate knowledge and its didactic transposition to the classroom.

- Build didactic sequences appropriate to the profile of the students, but at a higher level of demand than their previous knowledge.

- Use various teaching strategies and apply the most appropriate at all times. Detect learning problems, find solutions for them and make the pertinent curricular adaptations.

- Apply ICT in the classroom.

\section{SOCIAL SKILLS:}

- Understand teamwork in the center as a habitual method of professional identity and to make collegiate decisions regarding: teaching coordination, programming, planning ...

- Actively participate in the processes of elaboration of the projects in which the autonomy of pedagogical management of the centers is specified.

- Facilitate communication and dialogue with students and their families, and know how to act as a tutor (mentoring and coaching).

- Encourage relationships with environmental agents and support services that can improve socialization and autonomous learning of students.

\section{PERSONAL SKILLS:}

- Assume the professional identity (mathematician versus math teacher) in a positive and creative way.

- Accept the deontological code of the teaching profession and put it into practice.

- Get involved in conflict resolution, that is: assume the educational function simultaneously to that of facilitating and accompanying in the construction of knowledge.

- Learn to share good educational experiences.

- Improve educational practice based on the results of evaluations (of everything and everyone). 


\section{DESCRIPTION OF THE EDUCATIONAL CENTER}

The present work adheres to a fictitious situation that would take place in a class with 2nd ESO students from the "Príncipe de Asturias" IES, which is located in the Murcian town of Lorca, located in the San Diego neighborhood.

This neighborhood is known for its rich cultural and racial diversity, since a large number of people of different nationalities in addition to Spanish (Arab, Ecuadorian, Peruvian, African, etc.) live here, with the majority being immigrants. Likewise, the neighborhood is also known for being located in a prominent and relatively central part of the city, which makes it a place of significant contrast on a socioeconomic level. Thus, we find families of lower-middle (mainly), middle class social class, and to a lesser percentage, upper-middle class. The profile of the students in the "Prince of Asturias" therefore adheres to these characteristics.

The number of students in our group-class will be 30 , since the ratio in this institute tends to be frequently on the rise.

\section{DESCRIPTION OF THE SITUATION TO BE DEALT WITH}

We present the (fictional) case of a student with disruptive behavior who shows low assertiveness when interacting with the rest of his classmates, but especially with the teacher. In this case, the teacher teaches, in the group-class of the student in question, the subject of English, 5 hours a week.

The student subjected to behavior typical of someone with little assertiveness and very close to the aggressive and passive-aggressive model, constantly follows behavioral guidelines far from what should be considered "appropriate" in the context of a class, such as abrupt interruptions to the teacher, defiant attitude in her verbal and non-verbal language, respond silently to questions asked about the content of the subject, episodes of anger and potentially aggressive attitude alternating with others of passivity and complete disinterest, generalized indiscipline and disobedience, constant complaints, etc.

\section{DESCRIPTION OF THE PROPOSAL FOR THE APPLICATION OF ASSERTIVE TECHNIQUES IN THE CLASSROOM AND STRATEGIES TO PROMOTE AND IMPROVE ASSERTIVENESS AND SOCIAL SKILLS IN THE CLASSROOM}

A series of psychopedagogical application instruments are established with the aim of identifying the reasons for non-assertive behavior in the student in the context of the English classroom, and modifying that behavior towards an assertive model. Ultimately, it is sought that the student is aware of their inappropriate behavior and decides to rectify it on their own, using the tools provided by the teacher and / or the center. 
For this, it is necessary for the teacher to follow a series of essential guidelines to show the student his good will and his help as a conflict mediator from a position that is always respectful to the student. To address this type of situation, we will make assertive communication (in all its forms) our faithful ally, since this type of communication allows us to start a conversation from a collaborative point of view, where the student does not feel like a simple receiver of information, but also has an opinion, and this deserves to be respected.

Below I will present several examples of concrete fictitious situations, likely to occur with the student profile described in the section "Description of the situation to be treated", and I will describe a series of strategies to favor and improve communication between this student-type and the teacher, and thus seek an assertive model beneficial for both and for the group-class as a whole.

These strategies will be based mainly on using the Assertive Techniques studied throughout the course, which I will put into practice according to a hypothetical context, adapting them according to the need of each specific communicative situation.

Example 1:

(The student is talking and laughing aloud with the classmate behind, thus interrupting an explanation from the teacher, to which he reacts by calling him by name and asking for silence with a very serious face).

Student: (Very angry, raising his voice) You have a mania for me ... just scold me!!

Teacher: You are right that on several occasions I have made you see that your behavior was not appropriate, but I want you to understand that, as your teacher, it is something that I must do so that the class follows its normal course, with no exceptions with any of you and always looking for the common good. However, if you feel like this because of the way I act, I would like you to tell me what you think I could do so that this does not happen again.

In this case, you choose to use the Assertive Agreement Technique in combination with the Assertive Question Technique. What is sought is that the student is able to recognize a position of empathy on the part of the teacher and that in turn he is in the position of the teacher at a certain moment. With the Assertive Question, we seek that the student considers what could be an appropriate solution that produces mutual advantages, and ideally that he reaches the conclusion that he must start by changing his attitude so that a scenario of positive change opens up.

Example 2:

(Continuation of the conversation described in example 1)

Student: Yes, of course ... whatever you say ... how disgusting everything (unintelligible murmurs). 
Teacher: Well, now you are in a very bad mood and it is not the way to see things clearly. I think it is convenient that we postpone this conversation until tutoring time so that we can discuss this topic in more detail in a calm way.

In this case, the Ignore Technique is used, taking care of the tone at all times and trying to be as empathetic as possible.

I consider it important to say that in these cases, despite the situation in the context of a class of English as a foreign language, it is obvious that the language used in the conversation should be the vehicular language (in our context, Spanish) to leave as clear as possible the message to be transmitted, as well as showing relative closeness to the interlocutor, who in this case is our disruptive student.

However, we can (as long as the situation allows it and the teacher considers it appropriate) to take advantage of the situation and add some vocabulary word or expression in English to try to "relax the environment" in a subtle way while we equip our students of tools that they can use in specific situations such as those experienced at that specific time.

When applying Assertive Techniques, we will always have to take into account the language that we use to achieve our objective as an assertive model. Thus, within assertive verbal language strategies, the volume and intonation of the teacher's voice should be calm and constant, but not elevated. On the other hand, the message that we give to the student must be clear and precise, for sure; without making you feel evaluated (or at least as little as possible) or threatened, since what we seek is to show (and seek to inspire) respect and credibility.

To achieve assertive communication, it is also essential to listen to the student actively in order to put ourselves in their place, although this does not mean that we have to agree with their thoughts or actions. If we cannot dedicate time to active listening in the middle of a lesson for obvious reasons, we will postpone the conversation for a more appropriate time and in a suitable space (such as tutoring time during school hours, in case of being tutors of the group of the student, or in the teacher's office in the extra hours of tutoring in which we can also invite the parents / guardians of the same if we consider it necessary).

Regarding non-verbal language, the teacher must maintain an upright and open body posture, without crossing his arms, and generally take care of his gestures, in order to show interest and sincerity to our student. In depending on which cases, it may be beneficial to subtly support the hips on the teacher's table to show closeness and relativize the topic of discussion (or even next to that of the student to whom we are addressing if what we are looking for is a little less-oriented conversation. group that could intimidate you and negatively influence decision-making). Eye contact, meanwhile, should be direct but never challenging, seeking to increase confidence in the student. 
Another important point to take into account in these situations in the classroom is the option of requesting clarification from our student, in order to identify and understand the meaning of the words and / or actions of the same and show interest in understanding their point of view. .

\section{CONCLUSION}

A secondary school teacher is competent when he knows how to simultaneously interrelate and coordinate the 4 competencies to apply them integrally to a specific professional situation, and he does so regularly, having acquired the ability to know how to transfer these competencies to new professional situations.

"A clear common trait in many of the PISA performing countries is that they are increasingly trying to make education a 'knowledge rich' profession. The challenge for modern educational systems is to create a profession rich in knowledge, in which those responsible for delivering educational services on the 1st line (teachers and schools) have both the authority to act and the information necessary to do so intelligently, with access to effective support systems that help them work with an increasingly diverse clientele of parents and students"

By way of conclusion, and taking into account everything previously stated in this work, we consider it imperative to know, practice, promote and perfect (in this order) the assertive behaviors that will lead to a necessarily more fluid communication between the students and the teacher, which will lead to a calmer and more relaxed classroom work environment and, therefore, less repressive for both parties. Therefore, it is the teacher's responsibility to apply the necessary tools to provide the ideal assertive model, firstly exemplifying them with their own way of interacting with students and lastly, providing them with these strategies through the Assertive Techniques that they must bring to your knowledge. 


\section{REFERENCES}

Alonso, J. M. R., \& Romero, M. G. (2020). Familia de alumnos con necesidades específicas de apoyo educativo: importancia de una correcta participación. In Claves para la innovación pedagógica ante los nuevos retos: respuestas en la vanguardia de la práctica educativa (pp. 3734-3739). Octaedro.

Alonso, J. M. R., Carrasco, L. G., Martinez, L. A., Gallego, L. M., \& Romero, M. G. (2020). Organización escolar. Importancia de la relación familia-escuela. Validación CPPRFE. Brazilian Journal of Development, 6(12), 102902-102915.

Alonso, J. M. R., López, M. E. M., \& Abellán, A. L. (2020). Didáctica a través de las emociones. Validación cuestionario percepción emocional del profesorado (PEP). Brazilian Journal of Development, 6(11), 91962-91979.

Alonso, J. M. R., Rosique, R. C., Pérez, R. S., Robles, C. M. S., \& Romero, M. G. (2020). Didáctica a través del cuento. Validación cupic. Brazilian Journal of Development, 6(12), 95146-95159.

Galian, A. L., Nicolás, Á. G., \& Alonso, J. M. R. (2021). School organization and confinement. Didactic focused on reducing the impact of covid. Peiwecs. South Florida Journal of Development, 2(1), 383-394.

García, S. G., Nicolás, A. H., Cano, M. G., \& Alonso, J. M. R. (2021). Giftedness in the students of the second cycle of childhood education. Intervention strategies in the classroom. South Florida Journal of Development, 2(1), 164-175.

González, M. G., \& Alonso, J. M. R. (2021). ICT in Primary Education. Review of its importance and a proposal. South Florida Journal of Development, 2(1), 131-144.

López-Alonso, J. M., Grumel, E., Cap, N. L., Trivi, M., Rabal, H., \& Alda, J. (2015, September). Characterization of dynamic speckle sequences using principal component analysis and image descriptors. In Optics and Photonics for Information Processing IX (Vol. 9598, p. 95980Q). International Society for Optics and Photonics.

Muñoz, J. G., Calderón, B. C., Melgar, R. M., \& Alonso, J. M. R. (2021). Importance of the use of interactive methodologies in primary education: gamification. Didactic proposal. South Florida Journal of Development, 2(1), 264-274.

Romero, M. G., \& Alonso, J. M. R. (2018). Aportaciones docentes sobre la programación docente en la etapa de Educación Infantil. In IV Congreso Virtual Internacional sobre Innovación Pedagógica y Praxis Educativa INNOVAGOGÍA 2018: libro de actas: 20, 21 y 22 de marzo 2018 (p. 43). AFOE. Asociación para la Formación, el Ocio y el Empleo.

Romero, M. G., Alonso, J. M. R., \& Romero, J. G. (2020). Aproximación conceptual a la disortografía. Aportaciones docentes. Brazilian Journal of Development, 6(4), 18814-18820.

Velázquez, A. B. G., Marín, P. O., López, Y. M., \& Alonso, J. M. R. (2021). Acercamiento a la atención a la diversidad desde la perspectiva de los profesionales de educación. Brazilian Journal of Development, 7(3), 20999-21014. 